\title{
Halal Tourism in Indonesia: Regional Regulation and Indonesian Ulama Council Perspective
}

\author{
Nurjaya $^{1^{*}}$, Vip Paramarta ${ }^{2}$, R. Roro Vemmi Kesuma Dewi ${ }^{3}$, Kusworo ${ }^{4}$, Surasni ${ }^{4}$, \\ Fika Rahmanita ${ }^{4}$, Syafaatul Hidayati ${ }^{4}$ and Denok Sunarsi ${ }^{4}$
}

\author{
${ }^{1}$ Universitas Suryakancana, Cianjur, Jawa Barat, Indonesia \\ ${ }^{2}$ Universitas Sangga Buana, Bandung, Jawa Barat, Indonesia \\ ${ }^{3}$ STAI Al Aqidah Al Hasyimiyyah, Jakarta Timur, DKI Jakarta, Indonesia \\ ${ }^{4}$ Universitas Pamulang, Tangerang Selatan, Banten, Indonesia
}

\begin{abstract}
The tourism sector is one of the sectors capable of increasing employment and economic growth. Currently, halal tourism is starting to be in great demand. This is in line with the increase in Muslim tourists from year to year. The development of halal tourism has begun to be carried out by various countries, both Muslim and non-Muslim countries. Indonesia as a multi-cultural and multi-ethnic country, of course, there are new problems that continue to surface where the law is not found either in the Quran or the Hadith, such as the emergence of the phenomenon of public demand for halal tourism in Indonesia. The purpose of this research is to describe halal tourism in Indonesia in terms of the Indonesian Council of Ulama fatwa and the government regulation. This research is a conceptual review that uses literature research methods sourced from authoritative journals, books, and documents and is still relevant to the study of halal tourism. The results showed that a large number of public requests for halal tourism visits in Indonesia in the need for normative and positive regulation regulates. the only difference is in the use of the term "sharia tourism" in the fatwa while the content in the regional regulation uses the term "halal tourism".
\end{abstract}

Keywords: DSN-MUI fatwa, regional regulation, and halal tourism.

\section{INTRODUCTION}

The World Travel \& Tourism Council in 2018 published a report on the economic impact of the travel and tourism sector (travel \& tourism) globally. Until 2017, the Travel \& Tourism sector was able to contribute $10.4 \%$. world gross domestic product (GDP) and absorbs 313 million workers or around $9.9 \%$ of the total workforce. This data shows the size and increasing importance of the role of the tourism sector for the economies of various countries in the world. Maldives, Macau, and several other countries have even made the tourism sector the main support of their economy with a contribution of more than $25 \%$ of national GDP. As for Indonesia, according to the Ministry of Tourism in 2017, the contribution of the tourism sector reached $5 \%$ of the national GDP (Kemenpar, 2018). Foreign tourists (foreign tourists) visiting

Indonesia in 4 years amounted to 10.23 million (2015) to 15.81 million people (2018). The increase in foreign tourists has implications for an increase in the contribution of foreign exchange provided, from $\mathrm{Rp}$. 175.71 trillion to Rp. 229.5 trillion. The number of workers absorbed by the tourism sector reached 12.7

*Address correspondence to this author at the Universitas Suryakancana, Cianjur, Jawa Barat, Indonesia; E-mail: nurjaya@unsur.ac.id million people (2018), an increase from 10.37 million workers (2015). This shows that the tourism sector can make a significant contribution to reducing the number of unemployed in Indonesia. Tourism is a trip taken by someone or more with the aim of, among other things, to get pleasure and fulfill the desire to know something (Gretzel et al., 2016). Tourism activity is one of the areas for economic development that has enormous benefits for a country (Pavihtra et.al, 2019). Tourist destinations and businesses engaged in this field can be expressed as a business ecosystem with high complexity because of the many interactions that occur involving various parties (Sanchez, 2017).

Tourism is a sector for growing the world economy which is very promising because the tourism sector is also a sector that is resistant to the global crisis, seen from the development of world travel which has experienced positive development since 1950 with 25 million tourist trips, in 1980 it reached 278 million people, 1995 reaching 528 million people, and 1.1 billion people in 2014 (Ratman, 2016). Chanin, et al. (2015) explained that the tourism industry is large and is seen as a sector that accelerates economic growth. The implication of the growing tourism industry which increase tourist visits, government revenue, can also provide benefits for local communities as a livelihood. This results in high competence between regions and tourist destinations to attract tourists. In Indonesia itself, tourism is the fastest-growing tourism sector and 
has become a sector. The Ministry of Tourism (2015) in its report noted that 13 provinces are ready to become halal tourism destinations, namely Aceh, Banten, West Sumatra, Riau, Lampung, DKI Jakarta, West Java, Yogyakarta, East Java, South Sulawesi, Central Java, Nusa Tenggara. West (NTB), and Bali. The Indonesian Ministry of Tourism has so far developed and promoted service businesses in the fields of hotels, restaurants, travel agencies, and spas in 12 Islamic tourist destinations. The development was carried out in several cities, namely Aceh, West Sumatra, Riau, Lampung, Banten, Jakarta, West Java, Central Java, Semarang, East Java, NTB, and South Sulawesi (Alamsyah, I. E, 2018). The halal tourism market is one of the fastest contributors to the growth of the tourism segment. It is projected that in 2020 contribution of halal tourism is targeted to contribute $35 \%$ or $\$ 300$ million to the global economic sector (Director Mastercard Indonesia, 2018). Indonesia has also won the 2019 GMTI version of the "World's Best Halal Travel Destination" award. Meanwhile, Indonesia's regional destinations that won the 2019 Indonesian Muslim Travel Index's "Best Halal Travel Destination" award are Lombok. Sharia tourism data in Indonesia starting from 2013, there are 37 new certified Islamic hotels and as many as 150 hotels heading for sharia operations. Likewise with restaurants, out of 2,916 restaurants, only 303 are halal certified. As many as 1,800 are preparing themselves as halal restaurants. Meanwhile, the place for relaxation, SPA is now only three units. A total of 29 are in the process of getting a certificate (Dini Andriani et al: 2015). In the national program, the Indonesian Ministry of Tourism has also set a target of 20 million foreign tourists, of which 5 million are Muslim tourists. In line with the seriousness of the government and related tourism supporters, as well as the potential of various tourist destinations in every region in Indonesia, it is not beyond impossible that Indonesia can become the main and foremost tourist destination in Indonesia.

The increasing number of human populations who make tourism a part of the necessities of life, and the development of technology that makes it easier for tourists to receive tourism information, will certainly have an impact on increasing the number of tourists both domestic and international, which will certainly impact the tourism industry. By applying the concept of smart tourism, the industry or field will get more competitive value or competitiveness in the eyes of tourists (Buhalis \& Amaranggana, 2014). Smart tourism or what is often called smart tourism is all forms of use of information and communication technology to obtain information related to tourism activities (Okty, 2017). Smart Tourism is the fastest way to increase economic growth (Pavihtra et.al, 2019). In this case, smart tourism is a concept that can be applied to various tourist attractions, be it natural, cultural, or artificial, and can also simulate various types of tourism destinations. One type of tourism that is currently developing and has potential in Indonesia is halal tourism. The reality of the increasing number of Muslim tourists provides a new segmentation for the tourism sector and affects the tourism industry around the world. Based on the report of the Standing Committee for Economic and Commercial Cooperation of the Organization for Islamic Cooperation (COMCEC, 2016) the Organization for Islamic and non-OIC Cooperation is estimated to reach 116 million in 2014 and is projected to grow to 178 million by 2020. Data from the Global Islamic Economic State 2014- 2015 stated that the halal business trend indicators seen in five industrial sectors continued to show progress. These include Islamic financial services, halal food, Muslim clothing, halal media and recreation, and halal medicines and cosmetics. The final report of the Ministry of Tourism's Sharia Data Development Study in 2016 shows that the Islamic economy is an important part of today's global economy. Seven sectors of the Islamic economy have experienced significant improvements, namely culinary, Islamic finance, the insurance industry, fashion, cosmetics, pharmaceuticals, entertainment, and tourism. Where all sectors carry the concept of halal in each product. The rise of products with the halal label creates a new halal-based ecosystem. In Indonesia, halal tourism has been developed into a national program by the Ministry of Tourism.

Knowledge and awareness of halal products make the growth of the halal industry increase (Rahman et al. 2011; Hamdan et al. 2013). The increase in the halal industry has led to halal tourism as a new phenomenon (Samori et al. 2016). This is also supported by various literature which explain that Muslim tourists care about the consumption of products and services according to sharia when visiting tourist attractions (Battour et al. 2010; Battour et al. 2012; Jafari and Scott, 2014). Interest in halal tourism has increased (Battour and Ismail, 2016). This increase is in line with the increase in Muslim tourists from year to year (Bhuiyan et al. 2011; Yusof and Shutto, 2014; El-Gohary, 2016; Handerson, 2016). Muslim tourists are expected to increase by 30 percent in 2020 and also increase the value of expenditures by up to 200 billion USD (Master Card and Crescent Rating, 2016). To explore the great 
potential of halal tourism, many countries (both Muslim and non-Muslim majority countries) have started to provide tourism products, facilities, and infrastructure to meet the needs of Muslim tourists. However, there are still many business people and parties involved in the tourism sector who are constrained in understanding (both products, facilities, and infrastructure) of halal tourism (El-Gohary, 2016; Mohsin et al. 2016; Han et al. 2018). The tourism sector plays an important role in the world economy because it is considered one of the contributors to job growth and economic growth in any country. So that tourism can also be seen as one of the most important sources of Gross Domestic Product (GDP). An increase in Muslim tourists is an opportunity and a challenge to improve the tourism sector. Based on this, this paper aims to analyze developments, concepts, opportunities, and challenges for halal tourism.

Based on the background that has been described above, the study about halal tourism in Indonesia, in the perspective of the DSN-MUI fatwa and Perda was very important to do and has a strategic value in exploring and finding standardization of alternative tourism indicators that are by the Qur'anic values and support the development of sustainable tourism through halal tourism in

\section{METHOD}

This research is a conceptual review that uses literature research methods sourced from authoritative journals, books, and documents and is still relevant to the study of halal tourism. This study uses a descriptive method with a qualitative approach that explains Indonesia's policy to make halal tourism an instrument to achieve national interest in economic issues and tourist visits through a positive image as a country that is friendly to halal tourism. The unit of analysis is the concept of Indonesian halal tourism and to explain the potential of the world halal tourism market and the potential of halal tourism owned by Indonesia as an instrument of public diplomacy, the unit of explanation that explains the country's interests are influenced by internal factors, namely domestic which has the potential to develop halal tourism, and External factors, namely the potential for halal tourism and Muslim tourists who continue to experience development.

\section{RESULT AND DISCUSSION}

Based on this, the development of halal tourism in the future is considered promising and potential.
Meanwhile, based on the results of research conducted by Utomo (2014), it is known that tourism potential is considered good and tourists agree with the concept of halal tourism. In terms of concept, $48 \%$ of respondents agree with the concept of halal tourism. In terms of need, $68 \%$ of respondents emphasized that halal tourism has high urgency in its implementation. In terms of suitability, $60 \%$ of respondents agree that halal tourism is by the conditions of Indonesian society. Based on this, the value that suits the needs of tourists is the hope of comfort and tranquility in the travel without forgetting Islamic values. This value is supported by the increasing middle-class Muslim community who have a high awareness of the halal of a product (Alim, Riansyah, Hidayah, Muslimin \& Adityawarman, 2015). That makes halal tourism have great potential to be developed following existing market demands. Indonesia synergizes with many parties to develop halal tourism, for example, the Ministry of Tourism in collaboration with the National Sharia Council (DSN), the Indonesian Ulema Council (MUI), and the Business Certification Institute (LSU). The concrete form of cooperation is to develop tourism and promote cultural and religious values which will then be described in the Minister of Tourism and Creative Economy Regulation (Jaelani, 2017). At present tourism has grown significantly in economic and social interests. The fastest-growing economic sector in most industrialized countries in the last few years is in the service sector. One of the largest segments of the service industry, although it's largely not recognized as an entity in some of these countries, is travel and tourism (Theobald, 2005). Therefore, tourism directly or indirectly has been at the forefront in the creation of a global community (Chang, 2007). Tourism according to the Law of the Republic of Indonesia Number 10 of 2009 concerning Tourism is a variety of tourism activities and is supported by various facilities and services provided by the community, business people, the Government, and the Regional Government. Lickorish and Jenkins describe tourism as an activity that crosses conventional sectors in the economy. This requires inputs that are economic, social, cultural, and environmental. In this case, it is often described as diversity (Lickorish and Jenkins, 1997). As also explained by Goeldner and Ritchie (2012: 4) who said that tourism is a combination of various activities, services, and industries that provide travel experiences: transportation, accommodation, places to eat and drinks, shops, entertainment, activity facilities, and hospitality services others are available for individuals or groups traveling away from home. 
In Islamic tourism, there are several main aspects required, namely the availability of halal food, adequate worship facilities, fast-breaking service during Ramadan, and restrictions on activities that are not sharia. Meanwhile, according to GMTI (2016), halal tourism facilities and services are places of worship, food, and drinks labeled halal, toilets with clean water, services and facilities. to support the month of Ramadan, free from alcoholic beverages and Sharia hotels. Awwal and Rini (2019), explain that GMTI standards that must be met in halal tourism include family-friendly destinations, Muslim-friendly services and facilities, and halal awareness and destination marketing. Whereas in the concept of smart tourism, the dimensions that must be built are informative, accessibility, interactivity, and personalization (Lee et al., 2017). Therefore, the development of halal tourism in Indonesia can be implemented as follows. Development of family-friendly destinations, with priority on regional destinations that are proclaimed as the best halal tourist destinations such as Lombok and Aceh. Ensure that tourist areas are free from alcoholic beverages and separate the Brotherhood and the sisters in public tourist attractions. Development of Muslim-friendly services and facilities, with the provision of places of worship that are not far from the destination, food and drinks labeled halal, toilets with clean water, services, and facilities to support the month of Ramadan, Tour and Travel which makes tour packages that do not conflict with prayer times, and provision of Sharia hotels. Development of halal awareness and destination marketing, with halal certification from $\mathrm{MUI}$ for each standardization of facilities to create a sense of security, comfort, and hygiene in consuming tourist services or goods. Then under development. Islamic tourism as a concept has been used with different terms and connotations in tourism theory and practice. Halal tourism (halal tourism), halal travel (halal travel), Islamic tourism, and Muslim friendly tourism (Muslim friendly tourism) are the most common terms, which are used as alternatives. Also, there are several related terms such as "halal hospitality", "sharia-compliant hotels", "halalfriendly travel" and Muslim-friendly destinations that allude to services in this sector (SESRIC, 2018: 3).

\section{The Importance of DSN-MUI Fatwa and Regional Regulation of Halal Tourism}

In this case, The Indonesian Council Of Ulama (MUI) has issued a fatwa on the implementation of tourism based on sharia principles Number: 108 / DSNMUI / IX / 2016. The fatwa contains the implementation of sharia-compliant tourism including, among other things, tourists, travel agents, entrepreneurs tourism, hotels, tour guides, and therapists. The NTB regional government also has West Nusa Tenggara Regional Regulation Number. 2 of 2016 concerning Halal Tourism. This fatwa and Regional Regulation also answers the phenomenon of halal tourism which is becoming a trend in Indonesia and internationally. So that this fatwa and Regional Regulation become a necessity for all halal tourism stakeholders in organizing tourism activities by sharia principles. Majelis Ulama Indonesia (MUI) through the National Syari'ah Council (DSN) has issued Fatwa Number 108/ DSN-MUI/X/2016 concerning Guidelines for Implementing Tourism Based on Sharia Principles. Some of the aspects regulated in the DSN fatwa are sharia hotels/inns; tourist destinations; spa, sauna, and massage; sharia travel agency; sharia tour guide. This study uses the criteria or provisions for sharia tourism according to the MUI DSN fatwa with several adjustments. Considering that Islamic hotels, Islamic travel agencies, and Islamic tour guides do not exist explicitly, specifically for these three aspects the term "sharia" is eliminated. However, the criteria or indicators that become the substance of the three aspects of tourism remain a reference. Likewise, several normative matters in the DSN fatwa that were not easily measured were also eliminated, such as the criteria for tourist destinations that "create the general benefit" and "create universal goodness.

The existence of the MUI fatwa viewed from the social aspect is considered very important (urgent) amid the reality of the plurality of Indonesian Islamic society. The role of the MUI fatwa is highly desirable to unite this diverse society. In line with its function and role as intellectuals, the MUI carries a great mandate to be able to accommodate the abilities or strengths that exist in itself for the benefit of society in general and Muslims in particular (Johar, 2019: 4). Although the existence of the MUI is mentioned in various legal products such as the Halal Product Guarantee Act, the MUI still insists that they are non-governmental organizations outside the government (Abdillah and Novianto, 2019: 112). As an Islamic institution and nongovernmental organization in Indonesia, MUI has always been independent (Habibaty, 2017: 447). In addition to issuing and stipulating fatwas (Wahyudi and Fajar, 2018: 121), the Indonesian Council Of Ulama (MUI) also guides Muslims and the government. MUI has the influence and legal authority of its fatwa, has given it the role and new institutional authority in many 
matters, such as matters of halal certification, Islamic finance, and pilgrimage (Lindsey, 2012: 253). travel (for various reasons, including directly related to Islamic law, such as Hajj and Umrah) (El-Gohary, 2015). In the Koran, many verses support the journey, which are contained in Ali-Imran: 137; Al-An'am: 11; Al-Nahl: 36; Al-Naml: 69; Al-'Ankabut: 20; Ar-Rum: 9 and 42; Saba ': 18; Joseph: 109; Al-Hajj: 46; Fathir: 44; Ghafhir: 82 and 21; Muhammad: 10; Jonah: 22; and Al-Mulk: 15. These verses from the Al-Quran support a journey with spiritual, physical, and social goals (Zamani-Farahani and Henderson, 2010). From these verses, it can be learned that a deeper surrender to Allah is made possible by seeing first-hand the beauty and gifts creation, and understanding the smallness of humans can magnify the greatness of God. Travel can also improve health and reduce stress, making it possible to pray better. The relationship between tourists (guests) and religion is also emphasized, that Muslims as hosts must provide hospitality to tourists. In Islam, the safar (journey) prayer is more granted (Hashim et al. 2007). So that Islam has a great influence on travel and encourages tourism. Halal tourism arises from the needs of Muslim tourists according to Islamic teachings, namely by the Al-Quran and Hadith. Thus, the concept of halal tourism is an actualization of the Islamic concept, namely the value of halal and haram which is the main measure. This means that all aspects of tourism activities are inseparable from halal certification which must be a reference for every tourism actor (Chookaew et al. 2015). MUI has the mission of Khidmatul Ummah as an aspect of service; Himayatul Ummah protects the ummah from the practices of the ummah's life which are forbidden in Islam. Including protecting people from consuming products that are not clear halal. Also as Shodiqul Hukumah or a government partner who helped guide or direct the government about socio-religious aspects in the life of the nation and state (Amin, 2018). In carrying out its mission The Indonesian Council Of Ulama (MUI) formed the National Sharia Board (DSN) which is tasked with overseeing and directing financial institutions and Islamic business institutions to encourage the application of Islamic teachings in financial and economic activities. DSN was formed through a Decree of the MUI Leadership Council on the Establishment of the National Sharia Board (DSN) Number. Kep-754/MUI/I//99 (Fateh, 2018: 158).

One of the challenges in developing halal tourism is related to marketing because marketing halal tourism is not an easy one. This is due to the difference between the demands of non-Muslim tourists and Muslim tourists. Non-Muslim tourists can decide not to travel to a tourist attraction without certain attributes (Battour et al. 2011; Battour and Ismail, 2016). So that one of the challenges of halal tourism is how to serve non-Muslim tourists and meet their needs without colliding with the concept of halal tourism. For example, some hotels state that they are Islamic hotels in their promotion and this may not appeal to non-Muslim tourists. Therefore, halal tourism can be an obstacle in the tourism industry sector. However, it can also be a business opportunity to use creativity and flexibility in serving the various needs of Muslim and non-Muslim tourists. This can also be a study or research to solve the problem. In general, the urgency of halal tourism regulations and regulations on halal tourism is to protect Muslims and Indonesian people so that their behavior is maintained and by the rules of Islamic law when traveling or carrying out tourism activities. This is in line with the objectives of the Indonesian Council of Ulama and Regional Regulations, namely to create a safe and harmonious society by the principles of sharia (halal) and the basis of the State of Indonesia (Pancasila).

\section{Sharia or Halal Tourism Indicators According to DSN-MUI and Regional Regulation}

The needs and demands of Muslim tourists for halal tourism as a whole must be captured as halal needs that are rooted in Muslim lifestyles (Islam and Kärkkäinen, 2013: 43). Because the core of sharia tourism (halal tourism) is understanding the meaning of sharia and its implementation in all aspects of tourism activities ranging from lodging facilities, transportation facilities, facilities, food and beverages, financial systems, to the facilities and providers of tourism services themselves (Priyadi, 2016: 92). The following are indicators of sharia tourism (halal tourism) extracted from the fatwa of the Indonesian Council of Ulama National Sharia Board Number: 108/DSNMUI/X/2016 Regarding Guidelines for Organizing Tourism Based on Sharia Principles.

In the fatwa, DSN MUI uses the term "sharia tourism" while the content in the Perda uses the term "halal tourism". The Regional Regulation also states that the halal tourism industry is tourism businesses that sell tourism services and products that are based on sharia principles as stipulated by DSN-MUI. Halal Tourism is also defined as a tourist visit activity with tourism destinations and industries that prepare shariacompliant tourism products, services, and management facilities. An increase in Muslim tourists is an 
Table 1: Indicators of Sharia Tourism (Halal Tourism) According to DSN-MUI

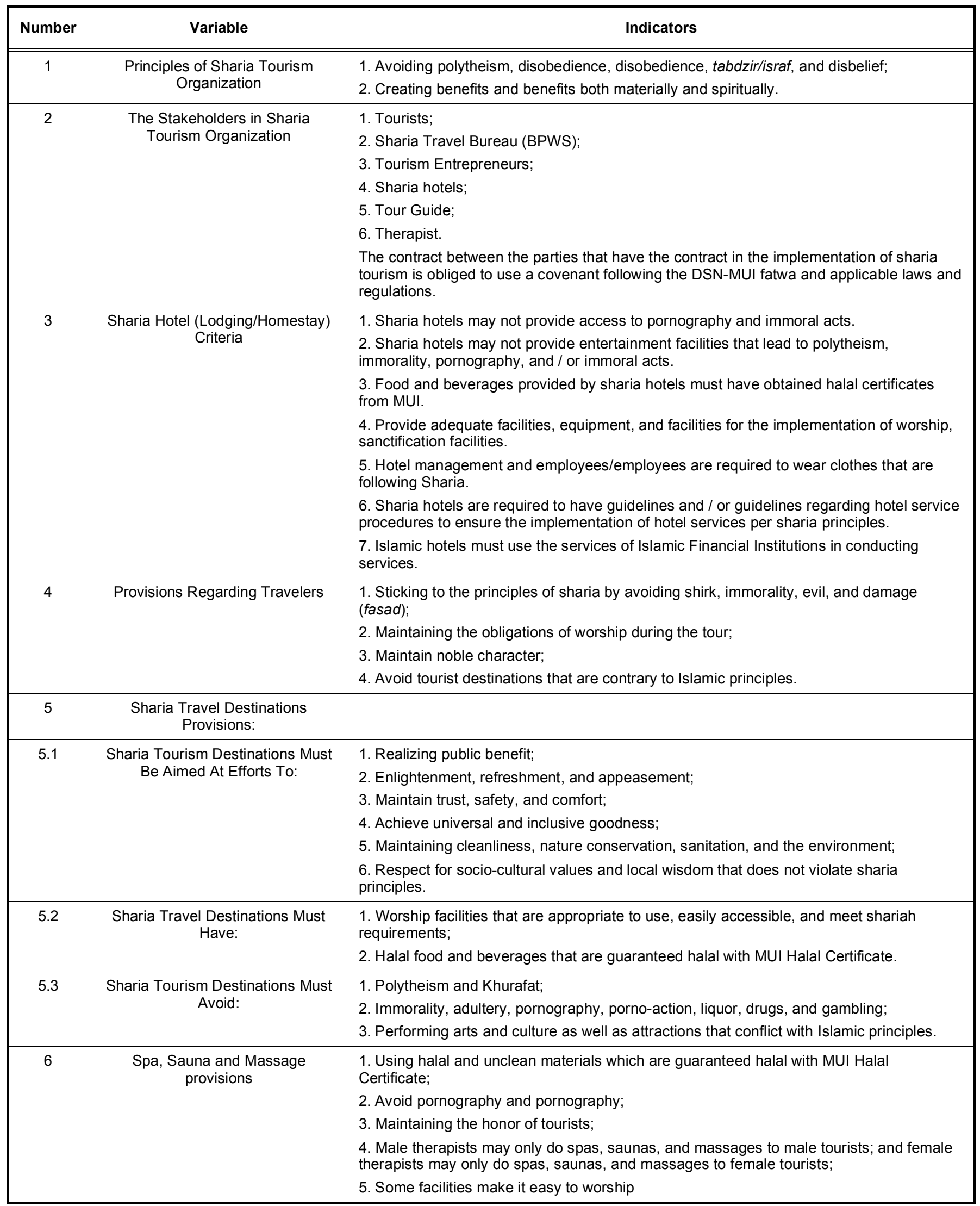


(Table 1). Continued

\begin{tabular}{|c|c|c|}
\hline 7 & $\begin{array}{c}\text { Provisions Regarding Sharia Travel } \\
\text { Bureau }\end{array}$ & $\begin{array}{l}\text { 1. Organizing tourism packages that are following sharia principles; } \\
\text { 2. Have a list of accommodations and tourist destinations that are following Islamic } \\
\text { principles. } \\
\text { 3. Have a list of halal food and beverage providers that have MUI Halal Certificates. } \\
\text { 4. Using the services of Islamic Financial Institutions in conducting tourism services, } \\
\text { including banks, insurance, financial institutions, guarantee institutions, and pension funds; } \\
\text { 5. Managing funds and investments must comply with sharia principles; } \\
\text { 6. Must have a travel guide that can prevent acts of shirk, khurafat, immorality, adultery, } \\
\text { pornography, porno-action, liquor, drugs, and gambling. }\end{array}$ \\
\hline 8 & $\begin{array}{c}\text { Provisions Regarding Sharia Tour } \\
\text { Guides }\end{array}$ & $\begin{array}{l}\text { 1. Understanding and being able to carry out sharia values in carrying out their duties; } \\
\text { especially those relating to the fiqh of tourism; } \\
\text { 2. Having good morality, communicative, friendly, honest and responsible; } \\
\text { 3. Having work competence following applicable professional standards as evidenced by } \\
\text { certificates; } \\
\text { 4. Appear polite and attractive following sharia values and principles. }\end{array}$ \\
\hline
\end{tabular}

opportunity for the tourism sector to develop halal tourism. So that several countries have started to take this opportunity by developing halal tourism, both countries with a majority of Muslims and non-Muslims such as Japan, South Korea, Australia, and Thailand. It is hoped that tourist attractions, hotels, restaurants, airlines, travel agents, and all those involved in tourism can be involved in halal tourism. Travel agents have halal tourism opportunities in various fields (Battour and Ismail, 2016). The purpose of the Shariah standard is to obtain certification from DSN-MUI. In addition to transparency, accountability, and fairness in implementing halal tourism must be participatory based. Therefore community empowerment through halal tourism includes strengthening public awareness, and increasing the capacity and role of the community in business management, and increasing community income.

\section{CONCLUSION}

Indonesia has the largest Muslim population in the world. Indonesia and Indonesia have also won the 2019 GMTI version of the "World's Best Halal Travel Destination" award. Meanwhile, Indonesia's regional destinations that won the "Best Halal Travel Destination" award from 10 other halal destinations in Indonesia, the Indonesian version of the Muslim Travel Index 2019 were won by Lombok Destinations. Meanwhile, the development of halal tourism in Indonesia can apply elements of developing familyfriendly destinations, services, and facilities that are Muslim friendly, and aware of Halal, and destination marketing programs that can be simulated by utilizing the concept of smart tourism by building informativeness, accessibility interactivity, and personalization for Muslim tourists. Indonesia as a multi-cultural and multi-ethnic country, of course, there are new problems that continue to surface where the law is not found either in the Quran or the Hadith, such as the emergence of the phenomenon of public demand for halal tourism in Indonesia. Halal tourism is a study that has begun to develop in recent years. The use of terminology related to halal tourism also varies and is still being debated. Likewise, the principles and/or main conditions of halal tourism have not been agreed upon. However, the availability of halal food, products that do not contain pork, drinks that are not intoxicating (containing alcohol), the availability of prayer room facilities including ablution places, the availability of the Koran and prayer equipment (prayer) in the room, qibla instructions and staff clothes being polite is a condition that can create a Muslim-friendly atmosphere. The increase in Muslim tourists from year to year is an opportunity and challenge for the tourism sector to develop halal tourism. Many countries (both Muslim and non-Muslim majority) are trying to develop halal tourism. However, judging from the existing concepts and principles of halal tourism, these countries generally only try to create a Muslim-friendly atmosphere. Development of halal tourism needs to be done, one of which is by conducting various studies or studies. Until now, research related to halal tourism is still limited, especially in Indonesia. One of the possible studies is related to the perception of non-Muslim tourists towards halal tourism.

\section{REFERENCES}

Abdillah, Ali and Rico Novianto. (2019) . "Lembaga Quasi NonGovernmental Organization (QUANGO) dalam Sistem 
Ketatanegaraan Indonesia: Majelis Ulama Indonesia". Jurnal Hukum \& Pembangunan. Volume. 49. No. 1. https://doi.org/10.21143/ihp.vol49.no1.1913

Adinugraha, Hendri Hermawan, (2018) "Desa Wisata Halal: Konsep Dan Implementasinya Di Indonesia". Human Falah. Volume. 5. No. 1.

Aryani, S. W., Sunarti, \& Darmawan, A. (2017). Analisis Dampak Pembangunan Pariwisata Pada Aspek Ekonomi dan Sosial Budaya Masyarakat (Studi Kasus pada Desa Wisata Bejiharjo, Kecamatan Karangmojo, Kabupaten Gunungkidul D.I.Yogyakarta). Jurnal Administrasi Bisnis Vol. 49. No. 2 Agustus 2017, 142-146.

Aryunda, H. (2011). Dampak Ekonomi Pengembangan Ekowisata Kepulauan Seribu. Jurnal Perencanaan Wilayah dan Kota, Vol. 22, No. 1, April 2011, 1-16. https://doi.org/10.5614/jpwk.2011.22.1.1

Ayad, N. (2012). Rethinking Strategic Public Diplomacy: the Role of Social Media. Diplomatic Academic Proceedings (pp. 23-32). Republic of Croatia: Diplomatic Academy Ministry of Foreign and European Affairs Republic of Croatia.

Baharuddin, (2015) "Understanding the Halal Concept and the Importance of Information on Halal Food Business Needed by Potential Malaysian Entrepreneurs". International Journal of Academic Research in Business and Social Sciences. Vol. 5. No. 2. 2015 https://doi.org/10.6007/IJARBSS/v5-i2/1476

Battour, M., \& Ismail, M. N. (2015). Halal tourism: Concepts, practises, challenges and future. Tourism Management Perspective Volume 19, Part B, 150-154. https://doi.org/10.1016/j.tmp.2015.12.008

Battour, Mohamed and Mohd Nazari Ismail. (2016) "Halal Tourism: Concepts, Practises, Challenges and Future". Tourism Management Perspectives. 19. https://doi.org/10.1016/j.tmp.2015.12.008

Bon, Maedeh and Mazhar Hussain (2010). "Chapter 4 Halal" In Tourism in the Muslim World Bridging Tourism Theory and Practice. Volume. 2. Amerika Serikat: Emerald Group Publishing Limited.

https://doi.org/10.1108/S2042-1443(2010)0000002007

Cholis, Azzah Fauziyah (2019). "Sharia Tourism Development Strategy in Natural Recreation Sites Of Batu City, East Java". International Journal of Applied Sciences in Tourism and Events. Vol. 3. No. 1.

Committee Cooperation for Development. Muslim Friendly Tourism: Developing and Marketing MFT Products and Services in the OIC Member Countries. Turki: COMCEC Coordination Office. 2016.

Economic Research Department Dubai Chamber of Commerce and Industry. Major Trends in The Global Islamic Economy. 2014.

Effendi, T. D. (2013). Diplomasi Publik Sebagai Pendukung Hubungan Indonesia-Malaysia. Jurnal IImu Hubungan Internasional Universitas Parahyangan, 47-61.

Eid, Riyad and Hatem El-Gohary. "Muslim Tourist Perceived Value in the Hospitality and Tourism Industry". Journal of Travel Research. Vol. 54. No. 6. 2014. https://doi.org/10.1177/0047287514532367

Elias, Ezanee Mohamed et al. "A Study of Halal Awareness and Knowledge among Entrepreneur Undergraduates". International Journal of Supply Chain Management. Vol. 5. No. 3. 2016.

Fahham, A. Muchaddam. "The Challenge of Developing Halal Tourism in Nusa Tenggara Barat". Aspirasi. Vol. 8. No. 1. 2017.

Fariana, Andi. "Urgensi Fatwa MUI dalam Pembangunan Sistem Hukum Ekonomi Islam di Indonesia". Al-Ihkam. Vol. 12. No. 1. 2017. https://doi.org/10.19105/al-ihkam.v12i1.1191
Fateh, Mohammad. "Konstruksi Filosofis Fatwa DSN-MUI". Jurnal Hukum Islam. Volume. 16. No. 2. 2018. https://doi.org/10.28918/jhi.v16i2.1736

Garit Bira Widhasti., et. all. (2017). Diplomasi Publik Pemerintah Republik Indonesia Melalui Pariwisata Halal. Jurnal Solidaritas: IImu-IImu Sosial, Volume 1, Nomor 1, Tahun 2017, 8 .

Goeldner, Charles R. and J.R. Brent Ritchie. Tourism: Principles, Practices, Philosophies, 12th ed. New Jersey: John Wiley \& Sons, Inc. 2012.

Habibaty, Diana Mutia. "Peranan Fatwa Dewan Syariah Nasional Majelis Ulama Indonesia Terhadap Hukum Positif Indonesia". Jurnal Legislasi Indonesia. Vol. 14. No. 04. 2017.

Hairey, L. S. (2013). Dampak Pariwisata Terhadap Pendapatan dan Tingkat Kesejahteraan Pelaku Usaha di Kawasan Wisata Pantai Nestapa, Pulau Ambon. Jurnal Organisasi dan Manajemen Volume 9, Nomor 1, Maret 2013, 87-105.

Hudson, Simon. Tourism and Hospitality Marketing: A Global Perspective. London: SAGE Publications Ltd. 2008. https://doi.org/10.4135/9781446280140

International Trade Centre. From Niche to Mainstream Halal Goes Global, Geneva: The International Trade Centre (ITC). 2015.

Isa, Salmi Mohd, et al. "Muslim Tourist Perceived Value: A Study on Malaysia Halal Tourism". Journal of Islamic Marketing. Vol. 9. Issue. 2. https://doi.org/10.1108/JIMA-11-2016-0083

Islam, Md. Aminul and Laura Kärkkäinen. "Islamic Tourism as A Prosperous Phenomenon in Lapland". Thesis. Degree Programme in Tourism. School of Tourism and Hospitality Management. Rovaniemi University of Applied Sciences. 2013.

Johar, Al Fitri. "Kekuatan Hukum Fatwa Majelis Ulama Indonesia (MUI) dari Perspektif Peraturan Perundang-Undangan di Indonesia". Article. $2019 . \quad$ http://panegarakalsel.go.id/images/images/PDF/Kekuatan_Hukum_F atwa_Majelis_Ulama_Indonesia.pdf.

Kamali, Mohammad Hashim. "Tourism and the Halal Industry: A Global Shariah Perspective". Islam and Civilisational Renewal. ICR 3.3. Institute of Advanced Islamic Studies (IAIS). 2011.

Kettani, Houssain. "Muslim Population in Asia: 1950 - 2020". International Journal of Environmental Science and Development. Vol. 1. No. 2. 2010. https://doi.org/10.7763/IJESD.2010.V1.28

The World Muslim Population, History \& Prospect. Singapore: Research Publishing. 2014

Laimer, Peter. "Basic Concepts and Definitions: Travel and Tourism (Domestic and International)". Paper. Regional Workshop for the CIS Countries. Tourism Statistics: Challenges and Good Practices. UNWTO/UNSD WS Moldova, 29 June - 2 July 2010.

Lickorish, Leonard J. and Carson L. Jenkins. An Introduction to Tourism. London: Butterworth-Heinemann. 1997

Lindsey, Tim. "Monopolising Islam: The Indonesian Ulama Council and State Regulation of the "Islamic Economy". Journal Bulletin of Indonesian Economic Studies. Volume. 48. Issue. 2. 2012. https://doi.org/10.1080/00074918.2012.694157

Ma'mur, Jamal. "Peran Fatwa MUI dalam Berbangsa dan Bernegara (Talfiq Manhaji Sebagai Metodologi Penetapan Fatwa MUI)". Wahana Akademika. Volume. 5. No. 2. 2018. https://doi.org/10.21580/wa.v5i2.3226

Mansouri, Shirzad. "Role of Halal Tourism Ideology in Destination Competitiveness: A Study on Selected Hotels in Bangkok, Thailand". Proceedings International Conference on Law, Education and Humanities (ICLEH'14). 2014. 
Mohsin, Asad et al. "Halal Tourism: Emerging Opportunities". Tourism Management Perspectives. 19. 2016. https://doi.org/10.1016/j.tmp.2015.12.010

Muhamad, Nur Sa'adah, et al. "Halal Tourism: Literature Synthesis and Direction for Future Research". E-Proceeding International Halal Management Conference (IHMC). Sejong University. Korea Selatan. 17-18 Agustus 2017.

Mulyati, Mumung. "Kontribusi MUI dalam Pengembangan dan Penerapan Hukum Islam di Indonesia". Al-Mashlahah: Jurnal Hukum dan Pranata Sosial Islam. Vol. 07. No. 1. 2019. https://doi.org/10.30868/am.v7i01.547

Namin A. A, Tajzadeh. "Islam and Tourism: A Review on Iran and Malysia". International Research Journal of Applied and Basic Sciences. Vol. 3. 2015

Pamukçu, Hüseyin and Özgür Arpaci. "A New Trend in the Turkish Tourism Industry: Halal Tourism". Global Issues and Trends in Tourism. Turki: ST. Kliment Ohridski University Presssofia. 2016.

Pew Research Center's Forum on Religion \& Public Life. The Future Global Muslim Population Projections for 2010-2030. Washington, D.C: Pew Research Center. 2011.

Pradesyah, Riyan and Khairunnisa. "Analisis Penerapan Fatwa MUI Wisata Halal (Studi Kasus Hotel Syariah Medan)". Intiqad: Jurnal Agama dan Pendidikan Islam. Vol. 10. No. 2. 2018. https://doi.org/10.30596/intiqad.v10i2.1986

Priyadi, Unggul. Pariwisata Syariah Prospek dan Perkembangan. Yogyakarta: UPP STIM YKPN. 2016.

Purwanto, H., Fauzi, M., Wijayanti, R., Awwaly, K. U. A., Jayanto, I., Mahyuddin, Purwanto, A., Fahlevi, M., Adinugraha, H. H., Syamsudin, R. A., Pratama, A., Ariyanto, N., Sunarsi, D., Hartuti, E. T. K. \& Jasmani, (2020) Developing Model of Halal Food Purchase Intention among Indonesian Non-Muslim Consumers: An Explanatory Sequential Mixed Methods Research. Systematic Reviews in Pharmacy, 11 (10), 396407. doi:10.31838/srp.2020.10.63

Saleh, Rahmat and Nur Anisah. "Pariwisata Halal di Aceh: Gagasan dan Realitas di Lapangan". Sahafa Journal of islamic Comunication. Vol. 1. No. 2. 2019. https://doi.org/10.21111/sjic.v1i2.2849
Sanad, Hassan Saad, et al. "Chapter 2 Tourism and Islamic Law". Tourism in the Muslim World Bridging Tourism Theory and Practice. Volume. 2. Amerika Serikat: Emerald Group Publishing Limited. 2010.

Setiyanto, Danu Aris. "Fatwa Sebagai Media Social Engineering (Analisis Fatwa MUI di Bidang Hukum Keluarga Pasca Reformasi)". Al-Ahkam. Vol. 3. No. 1. 2018. https://doi.org/10.22515/al-ahkam.v3i1.1342

State of the Global Islamic Economy 2017-2018.

Suharko, et al. "Institutional Conformance of Halal Certification Organisation in Halal Tourism Industry: The Cases of Indonesia and Thailand". Tourism Review. Vol. 66. No. 3. 2018.

Tawil, Norngainy Mohd, et al. "An Overview of Foodpreneur Awareness among Small and Medium-Sized Enterprises (SME) of Halal Certification". Asian Social Science. Vol. 11. No. 21. 2015. https://doi.org/10.5539/ass.v11n21p91

The Global Economic Impact of Muslim Tourism 2015/2016.

The World Tourism Organization (UNWTO). "Asia Tourism Trends 2017-Edition". Annual Report. 2017.

Theobald, William F. Global Tourism. Third edition. Amerika Serikat: Elsevier-Science. 2005.

Undang-Undang Republik Indonesia Nomor 10 Tahun 2009 Tentang Kepariwisataan.

Wahyudi, Heri Fadli and Fajar, "Metode ljtihad Komisi Fatwa Majelis Ulama Indonesia dan Aplikasinya dalam Fatwa". Cakrawala: Jurnal Studi Islam. Vol. 13. No. 2. 2018. https://doi.org/10.31603/cakrawala.v13i2.2402

World Tourism Organization. Understanding Tourism: Basic Glossary. 2018

World Travel \& Tourism Council. "Travel \& Tourism Economic Impact 2017". Report. Thailand. 2017.

Yusoff (2017). "Factor of Awareness in Searching and Sharing of Halal Food Product among Muslim Families in Malaysia". Proceedings. SHS Web of Conferences 33 i-COME'16. https://doi.org/10.1051/shsconf/20173300075

Received on 04-12-2020

Accepted on 08-01-2021

Published on 22-02-2021

DOI: https://doi.org/10.6000/1929-4409.2021.10.58

(C) 2021 Nurjaya et al.; Licensee Lifescience Global.

This is an open access article licensed under the terms of the Creative Commons Attribution Non-Commercial License (http://creativecommons.org/licenses/by-nc/3.0/) which permits unrestricted, non-commercial use, distribution and reproduction in any medium, provided the work is properly cited. 